\title{
AUDITORY EXTINCTION AND DICHOTIC LISTENING CV TASK IN CEREBRAL INFARCTION
}

\author{
PRELIMINARY REPORT
}

\author{
MAURO MUSZKAT* - J. OSMAR CARDEAL** \\ CLEMENTE I. RIBEIRO DE ALMEIDA *** - MARIA INEZ CAMPOS **** \\ CARLOS J. REIS DE CAMPOS *****
}

\begin{abstract}
SUMMARY - Six stroke patients were studied using a dichotic listening CV task, 4 with left hemisphere infarction, 2 with right hemisphere infarction. It was observed a «leston-effect», a shift of hemisphere prevalence to the side opposite a brain lesion. The authors suggest that the lesion-effect can be explained by the auditory extinction phenomenon at the linguistic level.
\end{abstract}

Estímulação dicótica CV em pacientes com acidente vascular cerebral: relato preliminar.

RESUMO - Foram estudados 6 pacientes com infarto cerebral mono-hemisférico utilizando 0 teste de estimulaçăo dicótica consoante-vogal (CV) para estudo da preferência hemisférica a estímulos verbais. Observou-se em todos os casos lateralizaçâo para o hemfsfério nắo comprometido, sugerindo a participação do fenômeno de extinçăo auditiva ao nivel lingtlistico.

Extinction to simultaneous stimuli is said to occur when one patient able to report a stimuli presented in isolation is unable to report the same stimuli presented simultaneously. In a brain injured person the extinction is related to the side opposite a brain lesion. Extinction can be found in varied sensory modalities, including visual, tactile and auditory. The first description of auditory extinction was made by Oppenheim 8 (1885) and later, Bender \& Diamond 1 (1965) pointed out the relationship between extinction and hemisphere mechanism of perception. In classical terms auditory extinction was evaluated only by non-verbal sounds like snapping fingers. Recently, the auditory extinction has been studied in verbal task, mainly in dichotic listening test with verbal material9. Dichotic listening developed by Kimura 5 involves the simultaneous presentation of two different auditory stimuli to right and left ear. Normal right-handed subjects tend to report right ear stimuli more accurately. Probably it is due to the specialization of left hemisphere to process verbal information.

The aim of this study was to observe the relationship between hemisphere prevalence in dichotic listening $\mathrm{CV}$ and the side of a brain infarction in stroke patients.

- Mestre em Neurologia, Neuropediatra do Setor de Investigaçăo e Tratamento das Epilepsias (SITE), Disciplina de Neurologia (DN), Escola Paulista de Medicina (EPM); ** Professor Adjunto, Doutor, Chefe do Setor de Doencas Neurovasculares, DN, EPM; *** Doutor, Proiessor Titular de Otorrinolaringologia, Faculdado de Medicina de Jundiaí **** Mestre em Fonoaudiologia, EPM; ***** Professor Adjunto, Doutor, Chefe do SITE, DN, EPM. 


\section{MATERIAL AND METHODS}

Six right-handed patients with stroke were studied. The selection criteria included: (1) stroke episcde at least 6 months before the study: (2) ro hearing loss or differences between right and left ear detected by bone-conduction test and tonal audiometry: (3) more than $90 \%$ correct monoaural stimuli identification for each ear of the same stimuli used in dichotic listening task; (4) no aphasia signs.

The dichotic listening task was an adaptation to Portuguese language 7 for the Consonant-Vowel Test (CV) 10. The procedure consists of exposition of 80 pairg of CV non-sense syllables presented simultaneously and bi-aural to both ear. The teat was presented to the subiects from Akay CS 705 Recorder via 2 channels audiometer connected to TDH-39 earphones. The dichotic CV test was administered using 40 pairg of $C V$ non-gense syllables (BA, DA, GA, CA, PA, TA) as stimuli with simultaneous onset of pairs. The test material way presented at $60 \mathrm{db}$ to both ears. The presentation of thi $\mathrm{CV}$ sylables includes all possible non-identical pairing of dichotic stimuli with an interstimulus interval of 6 seconds. Half way through the test, the 2 channels were reversed with respect to the ears via the audiometer. The patients say the syllable more clearly detected. Ear preference score (EPS) for dichotic listrning were estimated using the method of Johnson et al 4. Tie number of left ear correct responses was subtracted from the number of right ear correct responses, and the differerce was divided by the total number of right ear plus left ear correct responses (EPS $=R$ ear $-\mathbf{L}$ ear $/ \mathbf{R}$ ear $+\mathbf{L}$ ear). The rositive EPS reflects a right ear preference or a left hemisphere prevalence while a negative EPS reflects a left ear preference or 4 right hemisphere prevalence.

\section{RESULTS}

The ear preference score obtained in the six cases studied is shown in table 1.

\begin{tabular}{|c|c|c|c|}
\hline $\begin{array}{c}\text { Age } \\
\text { (years) }\end{array}$ & Sex & $\begin{array}{c}\text { Hemisphere } \\
\text { infarction } \\
\text { (CT scan) }\end{array}$ & EPS \\
\hline 60 & $F$ & RIGHT & 1.00 \\
\hline 63 & F & RIGHT & 0.80 \\
\hline 54 & $\mathbf{M}$ & LEFT & -0.35 \\
\hline 55 & $\mathbf{F}$ & LEGET & -0.20 \\
\hline 63 & $\mathbf{F}$ & LEFT & -0.40 \\
\hline 60 & $\mathbf{M}$ & LEFT & $-0,06$ \\
\hline
\end{tabular}

Table 1 - Ear preference score $\times$ brain lesion side in the 6 patients.

The age ranged from 54 to 63 years with a mean of 59.1 years. Cerebral infarction was observed in 6 patients, 4 in left and 2 in right cerebral hemisphere. In 4 left hemtsphere infarction patients we observed a right hemisphere prevalence (negative EPS) with a mean of 0.25 . In 2 right hemisphere infaction patients we found a left hemisphere prevalence (positive EuPs) with a mean of 0.9 .

\section{COMMENTS}

A shift of hemisphere prevalence to the non-lesional hemisphere, previously called «lesion - effect»11 can be explained by two ideas: (1) Structural - An adaptation of a non-lesional hemisphere to process a verbal stimuli. Johnson et al.4 found a left ear preference in 20 aphasic patients using a CV dichotic listening test. The left ear advantage is interpreted as reflecting the superiority of the right hemisphere over the damaged left hemisphere in auditory verbal perception ${ }^{2}$. In our cases the adaptation transfer of function from the left to right hemisphere seems to be unlikely. The advanced age of non-aphasic patients studied do not support the neuronal plasticity process. (2) Perceptual - A shift of a perceptive or attentional process related to $\mathrm{a}$ interhemispheric mechanism. 
Some authors 3,6 found a shift of speech perception in convergence areas lesions outside the primary sensory projection areas, which are thought to participate in a neural network of a lateral attention and extinction.

A verbal dichotic listening can be seen like a double stimulation test in auditory modality 9 . In fact we can suggest that the superiority of a non-lesional hemisphere to process a $\mathrm{CV}$ stimuli can be reflecting the auditory extinction phenomenon at the linguistic level.

\section{REFERENCES}

1. Bender MB, Diamond SP - An analysis of auditory perceptual defects with observations on the localization of dysfunction. Brain 88:675, 1965.

2. Crosson B, Warren L - Dichotic ear preference for C-V-C words in Wernicke and Broca's aphasias. Cortex 17:249, 1981.

3. DeRenzi w, Gentilini $\mathbf{M}$, Pattacini $\mathbf{F}$ - Auditory extinction following hemisphere damage. Neuropsichologta $22: 733,1984$.

4. Johnson JP, Sommerg RK, Weldner WF - Dichotic ear preference in aphasia. J Speech Hearing Res 20:116, 1977.

5. Kimurs D - Cerebral dominance and the perception of verbal stimull. Can J Psychol 167, 1961.

6. Mesulam MM - A cortical network for directed attention and unilateral neglect. Ann Neurol 10:309, 1981.

7. Muszkat M - Estinulaçăo dicótica em pacientes com epilepgía parcia!. Tese de Mestrado, Frscola Pauliata de Medicina. Săo Paulo, 1989.

8. Oppenheim H - Ueber eine durch eine klinisch bisher niciat verwerthete Untersushungsmethode ermitelte Form der Sensibllitatsstorung bei einseitigen Erkrankungen des Grosshirns. Neurol Ztrlb1 4:529, 1885.

9. Tanabe H, Nishikawa $T$, Okuda J, Shiraishi J - Auditory extinction to non-verbal and verbsl stímuli. Acta Neurol Scand 73:173, 1586.

10. Shankweiller $D$, Studdert-Kennedy $\mathbf{M}-$ Lateral differences in perception of dichotically presented synthetic CV syllables and steady-state vowels. J Acoust sioc Am 39:1256, 1966.

11 Schulorf CS Goodglass $\mathbf{H}$ - Dichotic listening, side of brain Injury and cerebral dominance. Neuropsychologia $7: 149,1969$. 